\title{
Metinsel İçerikli Anlatım Dilinde Kimlik ve Giydirilmiş Kimlik Temsili
}

\section{Identity and Dressed Identity Representation in Textual Content Narrative}

\section{Şule Sayan}

Arş. Gör., Ankara Hacı Bayram Veli Üniversitesi, Güzel Sanatlar Fakültesi, Resim Bölümü

email: sule.sayan@hbv.edu.tr (DORCID ID: https://orcid.org/0000-0002-6959-3452

\begin{abstract}
$\checkmark$ Trthenticate` $\mathrm{Bu}$ makale bilimsel etik ve kurallara uygun hazırlanmış ve intihal incelemesinden geçirilmiştir. Etik kurul onayı gerektirmemektedir.
\end{abstract}

Atıf (APA 6)/To cite this article

Sayan, Ș. (2021). Metinsel içerikli anlatım dilinde kimlik ve giydirilmiș kimlik temsili. Atatürk Üniversitesi Güzel Sanatlar Enstitüsü Dergisi, 27(46), 1-12. https://doi.org/10.35247/ataunigsed.816411

Makale Gönderim Tarihi/Received: 26/10/2020

Makale Kabul Tarihi/Accepted: 12/01/2021

Makale Yayın Tarihi/Published: 29/03/202

Research Article/Araştırma Makalesi

Öz

Dinamik bir kimlik kavramı ile yaşadığımız küresel çağda, çoklu aidiyetlerin anlaşılabilmesi için zamanla değișip yeniden yapılanabilir bir gösterge olarak kimliğe bakılmalıdır. Çünkü sınırları muğlaklașan dünyada birey, çoklu kimlikte varlık alanı oluşturabilir. Güncel sanatçılar disiplinlerarası söylemin olanakları içerisinde kimlik ve giydirilmiş kimlik kalıplarını da tartışmaktadır. 1980'lerden günümüze kimlik temsilleri başta görsel sanatlar olmak üzere çeşitli disiplinlerde, önceki dönemlerden farklı biçimlerde yorumlanmıștır. Metinsel içerikli anlatım dili, kimlik meselesini belirli toplumsal dinamiklerle okuma ve ifade etme pratiğinin yerine yeni bir öneri niteliği taşımaktadır.

$\mathrm{Bu}$ makalede genel çerçevede kimlik ve kimlik temsillerinin, güncel sanatta hareket alanı incelenmekte, yazıyı bir arac olarak kullanan sanatsal pratiklerin kimlik oluşumlarını nasıl ele aldığı değerlendirilmektedir. Araştırma, kimlik ve kimlik temsillerinin kuramsal boyutuna genel bir bakıș sunduktan sonra yazının kullanıldığı bir pratikten hareketle kimlik temsillerini günümüz sanatından örnek sanatçı işleri üzerinden incelemek ve değerlendirmek amacıyla gerçekleştirilmiştir. Yapılan görsel analizler, eser okumaları ve literatür taraması yoluyla, dilin temsili olan yazıyı bir yöntem olarak seçen sanatçıların çalışmaları, güncel sanat içerisinde konumlandırılmıştır.

Anahtar kelimeler: Güncel Sanat, Dil, Yazı, Kimlik, Temsil

\begin{abstract}
In the global age in which we live with a dynamic identity concept, identity should be viewed as an indicator that can change and be reconstructed over time to understand multiple attachments. The reason for this transformation is that the individual can create a domain of existence with multiple identities in such a world whose boundaries are getting blurred. Contemporary artists discuss identity and dressed identity patterns within the possibilities of interdisciplinary discourse, as well. As of 1980 , identity representations have been interpreted differently from previous periods in various disciplines, primarily in visual arts. The textual content narrative language has the nature of being a new proposal instead of the practice of reading and expressing the identity issue with certain social dynamics.

This article analyzes the action area of identity and identity representations in contemporary art and evaluates how artistic practices in which writing is used as a tool to address identity formation. After presenting an overview of the theoretical dimension of the identity and identity representations, the research was carried out to analyze and evaluate identity representations through the works of artists from contemporary art. Through visual analyses, work interpretations, and literature review, the works of artists who choose writing as a method representing the language are positioned in contemporary art.
\end{abstract}

Keywords: Contemporary Art, Language, Writing, Identity, Representation

\section{Giriş}

Sanat tarihine bakıldığında insanlığın belleği olan yazının farklı amaç ve alanlarda yer aldığı görülür. İletişimin bir aracı olan dilin temsili yazı, sanatın tarihsel sürecinde kimi zaman resmin içerisinde plastik bir öğe olarak yer alırken bazen sadece bir kavram ya da mesaj içerikli bir fikrin göstergesi olarak karşımıza çıkar. Yazılı metinler, bazen manipüle etme, tanıklık etme, göç, kadın ve erkek, kendi ve öteki gibi kolektif bellekte gizlenen hikâyenin bir temsil parçası olarak direkt aktarma biçimi olarak kullanılmışır. Bu perspektifle sanatçılar çalışmalarını üretirken tarihsel kökenlerinden, yaşadığı kültürden veya etnik kimliklerine başvurarak kimlik kavramı ve yazının kullanıldığı sanat pratikleri arasında bir ilişsi kurmuşlardır. Küresel olanın yaşamın her alanında sokakta, evde, televizyonda yoğun etkileşiminden dolayı, günümüzde sanatın ya da sanatçının küresel bir konu olan kimlik meselesinden etkilenmemesi beklenemez.

Metinsel içerikli anlatım dili, kimliği yüzyıllar boyu sadece belirli kültürel dinamiklerle okuma ve ifade etmenin yerine, yeni bir öneri niteliği taşımaktadır. Ayrıca yazının kullanıldığı sanat pratikleri, kimlik temsilleri üzerinden hareketle farklı1ıkları anlamamızı sağlayan sistematik bir kodlamadır. Kimlik kavramı ve temsil politikalarının önemli bir yer tuttuğu bu makale, kimlik kavramıyla ilgilenen sanatçılar için, metinsel ağırlıklı dilin etkin bir araç olarak kullanıldığını göstermeyi amaçlamaktadır. Ayrıca, sanatçının kimliğin dille nasıl tanımladığının ifadesi olarak yeni bir önerme sunmuştur. Dilin temsili olan yazının kimlik ile kurduğu beraberlikte metinler kimliklerin okunabildiği birer araç olarak görülmektedir. 
Çalışmada öncelikle toplumun dini, politik, siyasal, kültürel değer yargılarının bir ürünü olan; insanın çoklu kimliklerinin, bireysel ve çoğul bir olgu olduğu vurgulanmaktadır. Daha sonra kimlik ve kimlik temsillerinin, sanata yansımaları üzerinde durulmuştur. Son olarak kimlik temsiline, insanoğlunun tarih boyunca ifade biçimi olarak seçtiği metin içerikli anlatım dilinin göstergesi olan yazıyı kullanarak çalışmalar üreten, güncel sanatçıların örnek yapıtları üzerinden bakılmıştır. Makale, kimliğin sadece belli dinamikler çevresinde okunamayacağı tezini ileri sürmektedir. Öteki, siyahi, kadın, erkek ve alt kimlikler gibi daha önce yeterince gündeme getirilmemiş alanlardan, kimlik kavramını, yazı aracılığıyla, daha etkili ifade edildiği düşünce süzgecini oluşturmaya çalışmaktadır.

\section{Yöntem}

Bu araştırma, güncel sanatta yazının kimlik ile kurduğu beraberlikte metinsel içerikli pratiklerin irdelendiği nitel bir araştırmadır. Makale kapsamında konu ile ilgili görsel analizler, okumalar ve literatür taraması yapılarak veri toplandıktan sonra, kimlik temsiline yazıyı kullanarak çalışmalar üreten, güncel sanatçıların örnek yapıtları üzerinden bakılmıştır.

\section{Bulgular ve Yorum}

\subsection{Kimlik ve Giydirilmiş Kimlik Temsilinin Kuramsal Boyutu}

Kimlik, insanı toplumsal, sosyal, psikolojik, politik olarak sınıflandırma sürecidir. Bireyler tarafından bize atfedilen, kendimizle özdeş tuttuğumuz kimlik, bizi bir "isimli” yaparken aynı zamanda, bir vasıf belirtisidir. Birer nitelik ve özellik gösteren kimlik her şeyden önce farklılıkları da gösterir. Gleason'a göre, kimlik kavramı sosyal bilimlerde temel olarak birey ve toplum arasındaki ilişkiden bahsetmek için 1950' li yıllarda yoğun olarak kullanılmaya başlanmış, "Ben kimim?" ve "Ben nereye aitim?" sorularıyla bağlantılı bir kavramdır (Gleason, 2006, s. 194). Kimlik, etnik, ulusal, cinsel, toplumsal, dinsel vb. sahip olunan pek çok farklı boyutuyla incelenen bir kavramdır ve bu boyutlarla birlikte taşıdığı anlamlar da yine değișkenlik göstermektedir.

Bir insanı tanımlarken kullandığımız her bir sözcük, onun kimliğini bilinir kılan karakteristiktedir: kadın veya erkek, anne, sanatçı, Yahudi, beyaz, siyah gibi tüm nicelikler kimlik durumlarını oluşturur. Bu tür kimlikler insan benliğinde dinamik bir organizasyona göre ve hiyerarşik bir düzen içerisinde var olurlar. Bu nedenle atfedilen kimlikler, onu diğerlerinden ayıran, farkını ortaya koyan ve onu "belirli bir kişı”” yapan bir niteliktir. Bu kapsamda kimlik ile ilgili sayısız tanımlama sıralamak mümkündür.

Kimlik kavramının tarihine bakacak olursak, onun çok yeni bir kavram olmadığını görürüz. Ancak kimlik kavramı yeni olmamakla birlikte, 1980'lerden sonra sosyal bilimler ve sanatta tartışılan bir kavram haline gelmiștir. Kimliğin güncel tartışmalara sıklıkla konu olmasının ardında toplumsal cinsiyet, politik sınırların yeniden çizilmesi, hareketliliğin ve bunun sonucunda göçün yayıldığı coğrafyalar, ve medyanın müdahaleci tavrı ile açıklanabilir.

Kimlik bireysel bir olgudur. Ama burada dikkat çekilmesi gereken nokta, toplumun kuramsal yapısı kimliği değişime teşvik ederek, şekillendirebilmektedir. Yani günümüzde kimlik kavramının, bir kimlik yaratarak ebediyen ona bağlı kalmak, kimliği sabitlemek değil, sürekli olarak yeni kimlik seçeneklerini açık tutarak belirli bir kimliğin hegemonyasından kurtulmaktır (Şimșek, 2002, s. 32). Bunlar bir anlamda giydirilmiş kimliklerdir. Yani kimlik kurgulanmış ve yapaydır. Yalın haliyle giydirilmiş kimlik; içine doğduğumuz verili kimliklerle benliğin gelişmesi, değişmesi ya da ortamlar arasında sayısız değer sistemi, uyaran ve daha birçok nitelik arasından sosyalleşmesi sürecinde edinilen kazanılmış kimliklerdir.

Güncel tartışmalara sıklıkla konu olan kimlik kavramı öznelci anlayışı reddederek yapılmaktadır. Öznelci kimlik anlayışında kapalı ve bütünsel bir iç özden yola çıkılır. Kimlik tutarlı ve yaşam boyunca az çok aynı kalan gerçek özdür. Dolayısıyla bireyi dışarıya ve etkileşime kapalı, değişmez bir özün temsil edeceğine ve tanımlayacağına inanılır. Bu yaklaşım organizmanın, dış çevresini ve değişimini göz ardı etmesi ve kimliğin oluşumunda doğru bir yaklaşım olmadığı için eleştirilmiştir. Öznelci karşıtı bir anlayış olan; nesnelci yaklaşıma göre kimlik; organizmanın iç dinamikleri yanında bütün bir dış çevresiyle birlikte karşılıklı etkileşimler ve iletişim sonucu oluşmuş olan bir bütünlük, bir tutarlılık ve sürekliliktir (Marshall, 2000, s. 9-12). Bu yaklaşımda kimliğin inşa edilmiş olduğuna, dolayısıyla tarihsel ve yerel bağlamda değişkenliğe, ilişkiselliğe, toplumlar ve bireyler arası etkileşimine inanılır. Tüm kimlikler bir inşa ürünüdür. İnsan benliğinde yer alan farklı kimliklerin listesi potansiyel olarak sonsuz uzunluktadır: hangisi üzerinde yoğunlaşacağımız, hangisini öne çıkaracağımız, hangisiyle özdeşleşeceğimiz sayısız etkene bağlıdır (Weeks, 1998, s. 85). Bu perspektiften yola çıkıldığında kimlik kavramını tanımlamanın günümüzde çok yaygın bir yolunun onu tercihler bağlamında ele almak olduğunu söylemek yanlış olmaz. Dolayısıyla çalışma sınırları çerçevesinde kimlik, öznelci karşıtı bir anlayış temelinde ele alınmıştır.

Newman ve Newman'ın yaptığı geniş kapsamlı bir kimlik tanımı, tüm bu ve benzeri tanımları doğrudan ya da dolaylı olarak içermektedir: Kimlik kavramı, bireyin geçmişle ilgili özdeşimlerini, bugünkü rollerini ve geleceğe 
yönelik arzularını yaratıcı bir biçimde bütünleştirmesi üzerinde odaklanır. Bireyin geçmişinin sosyal tarihi ile bugünün ve geleceğin kültürel beklentileri arasında bağlantı kurar (1978, s. 164).

Önemli değişimlerin yaşandığı, farklılıkların ön plana çıktığı süreç içerisinde, Modern dönemin öteki olarak gördüğü eşcinseller, siyahiler, kadınlar, etnik gruba dahil olan insanlar seslerini duyurmak için ön plana çıkmışlardır. Önceki dönemlerden farklı olarak insan biliminin eleştiriye açık tutulması, insana yeni açılım olanaklarını sağlamıştır. Gilles Deleuze ve Felix Guattari (Deleuze ve Guattari, 1991) ötekilerin kendini duyurma çabasının altında yatan amacı, güncel olan iktidarı kabul etmeyerek, yerine yeni bir iktidar yönetiminin gelme isteğine bağlamaktadırlar. Bu yeni sistemde artık "öteki" leştirilenlerinde kendilerini ifade edebilecek hakları bulunmaktadır (Sarup, 1995, s. 142). Michel Foucault, bu mekanizmanın amacını, iktidar tarafindan belirlenen kurallara uyan, otoriteye katlanan bir birey yaratmaktır (Akay, 2000, s. 57). Bu baskıcı iktidar mekanizmasına Chris Weedon kişinin kendini idrakıyla, diğerlerinin onu tanımlaması arasında büyük farklılıklar olduğunu belirterek, kimliklerin kurumsallaşmış yapılar tarafından belirlendiğini söylemektedir (Weedon, 2004, s. 13). Oysa insanlar ırk, cinsiyet, cinsellik, güzellik ve çirkinlik, yaş ve fiziksel kapasiteyle tanımlama ölçütlerine göre tanımlanmaktadır (Mathews, 2004, s. 15). Ancak bu tanımların ötesinde toplumsal üretim araçları, kültür ve yerleşik iktidar gibi olguların kimliklerin belirleyicisi olduğu düşünüldüğünde bu unsurlar, belirli kimliklere yatkın bireyler üretmektedir. Bu kimlikler arasında süreç içerisinde değişen dinamik bir hiyerarşi de söz konusudur. Bu dinamizm organizmanın yaşamı boyunca sürer ve onun sürekli olarak kimliğini yenilemesini ve geliştirmesini sağlar. Bu sorgulama süreci genel olarak uzun bir süreçtir. Ancak bu hayatın normal akışı haline gelerek patolojik bir durum olmaktan çıkmıştır. Ne var ki, böylesine kapsamlı ve çok unsurlu bir senteze ulaşmaya çalışan tanımların aksine Serter daha radikal bir yaklaşımla: İnsanlığın varlığını koruması ve sürdürmesi için, insan kimliğinde, birleşmesi ve giydirilmiş kimlik gurubundan sıyrılarak, insan kimliğinin onurunu yakalaması gerekmektedir (Serter, 1996, s. 344-349) sözlerini ifade etmiştir. Bu yaklaşıma göre birey kimliği, insanın sahip olduğu öz cevherleri (akıl, ruh) barındırır. Bu bir anlamda bütün insanlık ailesinde ortak olup aynı kurallara bağlıdır. Ancak bu yaklaşım insan kimliğinin zaman içinde şekillenip, değişime uğrayabileceğini göz ardı etmektedir. Çünkü insan kimliğin oluşum sürecinde toplumun değer ve davranış kalıpları yapay bir kimliğin oluşumunu teşvik etmektedir. Böyle ikili bir yaklaşım bireyin kimlik ve kimlik temsillerinde hiç bitmeyecek bir mücadele demektir. Bu mücadele ise kimlik olgusunu hep dinamik ve canlı tutan, onu kalıplaşmaktan ve donmaktan uzaklaştıran bir etmendir.

\subsection{Kimlik Temsillerinin Sanata Yansıması}

Sanat tarihine bakıldığında, toplumsal kimlikleri oluşturan pek çok dinamiğin sanat eserlerinde yer bulduğu gözlemlenir. Bu dinamikler, geliştirdikleri inanç ve üretim biçimleriyle toplumların kimliklerini tanımlamaktadır. Örneğin, Firavunların mezarları olarak inşa ettirilmiş Mısır piramitleri, Firavun'un kimliğiyle özdeşleşen inanç sistemleri ve siyasi yapılarının bir simgesidir. Sınıfsal kimliklerin birer ifade aracına dönüştüğü Rönesans döneminde ise "portre", kimlik temsilleriyle özdeşleşen bir düzlemdedir.

Kimlik kavramı 1980'lerde yeni arayışlar ve yorumlarla sanata yeni anlamlar kazandıran sanatçıların öncülüğünde disiplinlerarası bir yaklaşımı da beraberinde getirmiştir. Ancak kimlik temsillerine sanat dünyasının yönelimi, özellikle 1960'ların sonunda feminist araştırmacıların sanatta deha, büyüklük ve erkeklikle ilgili uzun süredir yerleşik olan varsayımları sorgulayan feminist sanat akımıyla başlamışıı (Heartney, 2008, s. 242). Kristeva, Cxous, Irigaray gibi feminist teorisyenlerin düşünceleri göz önünde bulundurularak "eşcinsel sanat", "feminist sanat" gibi gruplandırmalar başlar (Çabuklu, 2004, s. 113-114). Bu bağlamda çoğulculuğu benimseyen ve "öteki" kavramına duyarlılık gösteren sanatçılar, cinsel kimlik, cinsiyet politikaları ve ayrımcılık gibi olgulara yönelerek yapıtlarını üretmişlerdir. Ayrıca ürettikleri çalışmaların Batılı sanat ortamlarına girmeye başlaması ile farklı kültürlerin sanatlarının, geniş kesimlere ulaşmasında etkili olduğu söylenebilir. Ancak sömürgecilik sonrası dönemin feministleri cinsiyetçilikten çok ırksal, sınıfsal ve etnik baskıya odaklanırlar. Batı feminizminde kültürler arasında kadınların, deneyimine gösterilen ilginin yetersizliğine tepki gösterirler.

20. yüzyıl süresinde kendine temsil olanağı bulamamış kesimler de kimlik ve kimlik temsillerine dokunarak Batı sanat ortamlarında ürettikleri çalışmaları sergileme firsatı bulmuşlardır. Artun (2013, s. 22), Afrika sanatının ilk kez 1996 yılında Fogg Sanat Müzesinde sergilendiğini ve böylece sanat tarihindeki yerinin meşrulaştı̆̆ını ifade etmektedir. Etnik köken, ırk, cinsel yönelim gibi kimlik sorunlarının sanata ve sanat söylemine girmesi ile birlikte, ilk defa kayda değer sayıda kadın ve farklı etnik kökenli olan sanatçının işlerinin müze ve galerilere girmesine yol açmıştır. Ancak bu sergilerde, sanatçıların yapıtlarının okumasının azınlık kimliğine (deri renkleri, toplumsal cinsiyeti ya da cinsel yönelimi) indirgendiği görülür (Heartney, 2008, s. 242).

Burada, Hal Foster'ın farklılık arayan düzeni ifade etmesi önemli görünmektedir:

Bu kaygılı arayış, bastırılmış ya da kayıp farklılığın geri getirilişini tehlikeye atmakla kalmayabilir; aynı zamanda sahte farklılıkların imal edilmesini, tüketilmek üzere farklılıkların kodlanmasını da kışkırtabilir. Farklılık imal edilebiliyorsa, direniş de edilebilir. Bu noktada eleştirel marjinalliğin bir mit olma olasılığı ortaya çıkıyor -liberal romantizm kisvesi altında gerçek farklılığın yok edilip, tüketilmek üzere yapay farklılığın yaratıldığı ideolojik bir tahakküm alanı (Foster, 2011, s. 172). 
Sonuçta bir nokta ve tarih veremediğimiz bu olgu ve olaylar, bütünü oluşturan her parçanın birbiriyle ilişkisi kurularak okunabilmektedir. Literatürdeki bu tür araştırmalar, ötekileştirilen grupların sanat pratiklerinde nasıl birleşik bir etki yaptığını gözler önüne sermesi bakımından önemli görülmektedir.

Cinsel kimlik ayırımcılığıyla başlayan mücadele, öteki" düşüncesinin birey üzerinde oluşan psikolojik etkilerini irdeleyen yapıtlarla devam ederken günümüz sanatında kimlik kavramının farklı yönlerini içeren yapıtlar üretilmiştir. Bu çerçevede, yeni arayışlar ve yorumlarla güncel sanata yeni kavramlar kazandıran çok kültürlü ve multidisipliner işler üreten sanatçılar kimlik olgusuna yönelmiş yapıtlarını bu yönde gerçekleştirmişlerdir. Sınırları zorlarken çıkan eserlerde yazılı imgelerden, kolaja, enstalasyona, karmaşık franktal görüntü ve seslere varıncaya kadar geniş bir olanaklar kümesinin varlığı söz konusudur.

\subsection{Kimlik Temsilleri Bağlamında Metinsel İçerikli Anlatım Pratikleri}

Güncel sanatta çoğunlukla tartışılan kimlik problemine ve çözümüne yönelik yaklaşımlarda metinsel anlatım dili sanatçı için toplumla düşüncesini paylaşma, iletişim kurma noktasında önem taşır. Kimlik temsilleri ve metinsel içerikli anlatım pratikleri başlıklı bu çoklu seçenekler arasında iki önemli nokta vardır. Birincisi güncel sanatın, sıklıkla rağbet ettiği bir alan olarak kimlik temsillerine bakışı ve metinsel pratiklerle ifadesi olmuştur. İkincisi kimlik ve kimlik temsillerinin metinsel ağırlıklı dil düzleminde etkin bir araç olarak kullanılma durumu ayrı bir, ikili alan olarak karşımızda duruyor. Bu iki konu şüphesiz birbirinden bağımsız değildir.

Günümüz sanatçısının bazen bir toplumbilimci, bazen bir ekolog vb. kimlikleri üstlenen sanatçı tipi yanında, kimlik olgusunu yazıyı kullanarak çalışan tüm sanatçıların farklı tavırlarından bahsetmek mümkündür. Kimliği dert edinen sanatçı, kimi zaman dili büyük harflerle sorgulayıcı bir tutumla sloganlaştırır, kimi zaman kısa ve öz metinlerle kültüre, yönetime, politikaya ve cinsiyetçi ayrımcılığa dair eleştirileri yazı üzerinden izleyene iletmekte ve izleyeni sorgulamaya ve dünyaya farklı bir gözle bakmaya teşvik etmektedir. Kimlik ve metin arası bu tamamlayıcı ilişside sanatçı yazıyı belgeleme amaçlı kullandığı gibi bazen kimlik üzerinden bir performansın içerisine dâhil ettiği kısa hikâyelerle bazen ise sadece yapıta dair ön bilgilendirme vermek amacıyla yazıyı tercih etmektedir. Tam olarak yaşamak ve anlamak için yaşanılana yakınlık kadar uzaklık da gerekir. Ve bilinç bu mesafeyi en kolay yazı yardımıyla tanır (Ong, 2013, s. 102).

Günümüzde sanatçıların bir pratik olarak metinsel içeriği kullanmalarındaki amacı; hikâye anlatma, doküman oluşturma, mesaj verme, anlatma-paylaşma isteği, var olduklarını ispat etme çabası gütme vb. yöntemlerle sıralanabilir. Güncel sanatın çoklu yapısında yapıtın hikâyesinin daha iyi anlaşılması ya da bazı boşlukları yanıtsız ve belirsiz bırakmamak içinde yardımcı bir öğe olarak kullanıldığı söylenebilir.

Nil Yalter örneği, bunun kadın kimliğinin temsiline yönelik ayağını göstermektedir. Bir çok eserinin çıkış noktası edebiyat olan Yalter, kadının sanattaki konumuna dikkat çekerek; video, performans, enstalasyon, fotoğraf gibi pratiklerle üretimde bulunarak, cinsiyetçi bir yaklaşımla kolektif kadın çalışmalarına ve sorunlarına temas etmiştir. Arzuladığım sanat tiyatroyu da içermeli, ama ayrıca resmi, dansı, müziği sözcükleri de içermeli... Başka bir deyişle son derece zengin, tümüyle yetkin bir şey istiyordum. Hiçbir şeyi eksik olmamalıydı (Hicks, 2015, s. 206) sözleriyle ifade etmiştir. Sanatçının çalışmaları konuşulmayan, unutulan, görmezden gelinen kültürel kimlikleri, cinsiyeti, göçleri marjinalleştirilmiş bireylerin hikâyeleriyle disiplinlerarası bir izleği takip eder. Yalter tüm bunları yaparken dilden, metinlerden ve edebiyat eserlerinden beslenen bir "hikâye anlatıcısı" olarak görülebilir. Cesur ve kendinden emin, arzunun gücünden yararlanan bir psikolojik etki sunan metinler yapıtın anlamını daha da güçlendirerek izleyiciyi yönlendirir ve özgün görsel bir dil kurar. Sanatçının üretim süreci boyunca edebiyatla ve metinlerle olan yoğun ilişkisine yazılı içerik bağlamında baktığımızda "Başsız Kadın veya Göbek Dans" (Görsel 1) adlı video çalışması René Nelli’nin "Erotique et Civilisations” isimli kitabından aldığı bir metni, sanatçının kendi göbek deliğinin etrafına, siyah keçeli kalemle yazmasıyla başlar. Metnin orjinali Afrika'nın bazı bölgelerinde yaygın olarak yapılan kadın sünnetine dair etnografik bir analizdir. 20 dakika süren siyah beyaz video çalışması, doğurganlığı artırmak adına, kadının karnına imam tarafından yazılar yazılmasından oluşan görüntüleri içerir. Video, Anadolu kadınının durumuna gönderme yaparken geleneksel yaşamın baskısı altındaki kadının doğal zevklerinden menedilmesine isyan eder (Tezkan, 2018).

Yalter' in Görsel 2'de formlarını doğu halı desenlerinden alan "Şu Gurbetlik Zor Zanaat Zor" serisinde ise, konfeksiyon işçilerinin fotoğrafları şair Nazım Hikmet'in (1901-1963) "Sürgün Zor Bir İş” sloganından yola çıkarak ilham aldığı Nâzım Hikmet ve Hasan Hüseyin Korkmazgil’ in şiirleriyle bütünleşiyor. Yalter kadın, yoksulluk, emek ve göç anlatılarının baş figürleri kadının yaşam öyküsünü odak noktasına alarak incelediği kadın cinsiyetinin görülmez bir varlık olmadıklarını ortaya koyar. Sanatçının kendisi de hem bir kadın hem de bir göçmen kimliğe sahip olduğundan gurbet konusu kendi kimlik çeşitliliğinden yansıyarak eserlerine eşlik eder. Sözü edilen eser, şiirden etkilenmiş olmakla beraber Yalter' in sıfırdan bir hikâye yaratımının da örneğidir. 


\section{Görsel 1}

Başsız Kadın veya Göbek Dansı

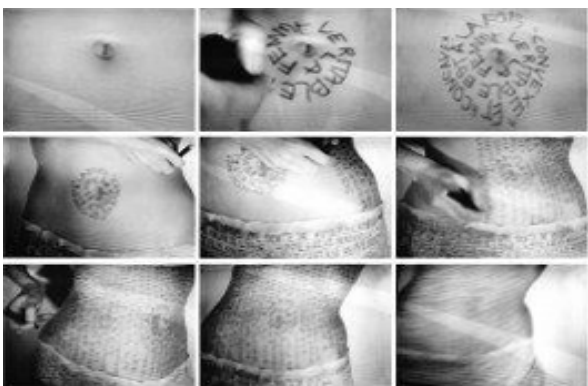

(Yalter, 1975).

\section{Görsel 2}

Şu Gurbetlik Zor Zanaat Zor

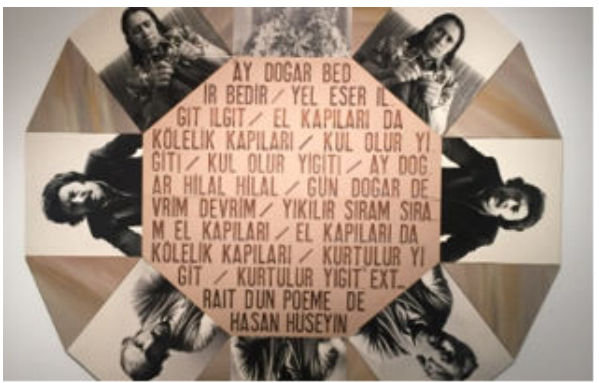

(Yalter, 2016).

Metinleri kullanarak izleyici ile buluşan sanatçılardan biri olan Tracey Emin yapıtlarında bellek izlerini, kimlik otoportresini izleyiciye sunar. Emin, toplumsal ahlakı, cinsel yargıyı, kadınlara yönelik tabuları, sanatıyla çekinmeden sorgular. Kadın kimliği altında yatan, yaşadığı tüm mahrem ve travmatik duyguları, metinler aracılığıyla sergilediğinde izleyiciler de sanatçının çektiği acıyı tüm detaylarıyla öğrenir. Sanatçı yazıyı samimi el yazısı karakterleriyle kimliği üzerinden bir günlük yazar gibi kullanmıştır. Seyirci, çalışmalardaki bu metinleri, tıpkı günlüklerden aktarılan bir hayatı gözetlemek veya gizlice okumak gibi yorumlayabilir. Emin, izleyiciye kendi hayatına açılan bir pencereyi bilerek aralamış gibidir.

Sanatçının yapıtlarında yazıyı daha çok iki şekilde kullandığı görülür. İlki Görsel 3'de yer alan eserde, neon 1şıklarla gerçekleştirdiği İtalik el yazısı karakter biçimidir. İkincisi ise, Görsel 4'de "patchwork" tekniğiyle yaptığı, el ile yazılmış gibi duran ve samimi bir etki yaratan büyük harflerle sanatçının çalışması, seyircinin karşısına çıkar. İzleyende sıcak bir ifade yaratan bu teknik Emin’in hayal kırıklığı, travma gibi duygular barındıran yaşantısının bir örneği gibidir.

“Neden?”, "Hangi Konu?”, "Hangi Malzeme?” gibi boşluk yaratan soruların yanıtsız kalmaması için sanatçının metinlerden, sözcüklerden ve açıklamalardan faydalanılması çalışmaya simbiyotik yani tamamlayıcı bir ilişki getirmiştir. Metin ve yapıt arası bu tamamlayıcı ilişkide sanatçının alt hikâyesi ve yapıta yansıtabildiği gizlenmişlik ve cinsel kimliği, metinler aracılığıyla çalışmaya dair ön bir bilgi vermesi açısından önemlidir.

Görsel 3

Fantastic to Feel Beautiful Again, Neon

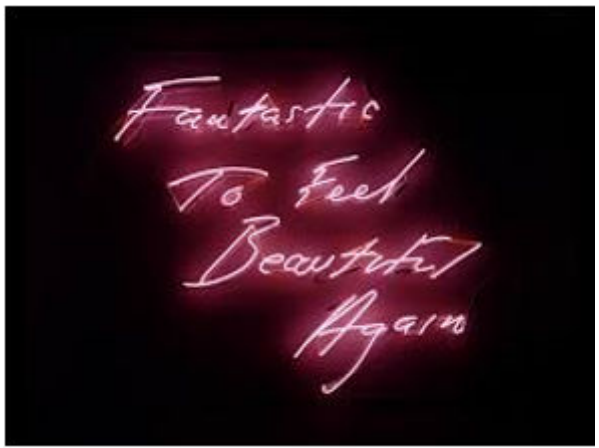

(Emin, 1997). 


\section{Görsel 4}

Hate and Power Can be a Terrible Thing

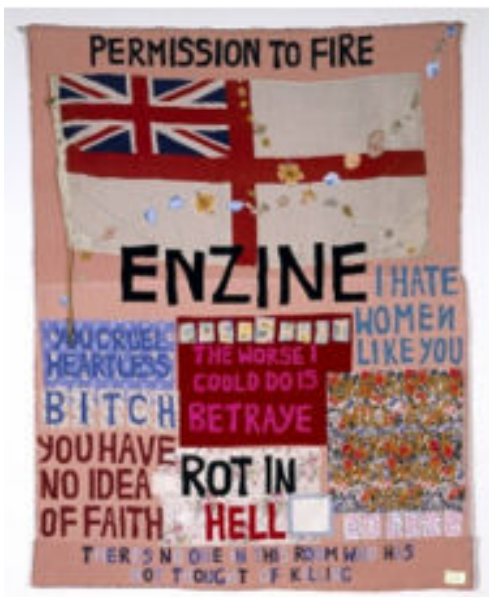

(Emin, 2004).

Toplumun marjinal olarak kabul ettiği kimlikler, cinsiyet politikaları üzerine çalışmalar yapmışlardır. Bu bağlamda ele alınan Act Up ve Gran Furry iki aktivist ortak, kuir kimliklerini agresif grafik görsellerle "Buradayız, tuhafız, buna alışın" gibi sloganlarla ifade ettiği çalışmalarla tanınmaktadır. Yüzlerce sözü basitçe tipografik bir dizilimle sıraladığı metinler, harekete geçirme, slogan, talep etme gibi içeriklere sahiptir. İkili, izleyici ile buluşmanın yolu olarak yazıyı seçer. Cinsel yönelimleri farklı olan ve AIDS ile yaşayan insanların kişisel deneyimlerini halk tarafından anlaşılabilir sembollere dönüştürmek için metinsel içerikli sokak sanatını ve posterleri kullanarak sanat ve kimlik çeşitleri arasındaki ilişkiyi analiz etmişlerdir. Özellikle mesajlarını dönemin medya araçları olan afişler, billboard ve otobüs giydirme gibi grafiksel ifade yöntemleriyle yayınlamışlardır (Heartney, 2008, s. 257-258). Gran Furry eserleriyle, yerleşik ve/veya değişebilen yani giyilip çıkartılabilen kimlik algısını ve kimliğin dinamik doğasını da akla getirmiştir.

İkilinin kimlik ve yazı üzerinden oluşturmaya çalıştığı örnek işlerinden biri (Görsel 5) kamusal alanda, kentte yaşayan insanlarla iletişim kurma noktasında diğer reklam görüntüleri arasında yer alıyor. Otobüs posteri olarak sergilenen çalışmada "öpüşen üç çift”" gösteriyorlar. Sloganları: "Öpüşmek Öldürmez: Açgözlülük ve Kayıtsızlık Öldürür.” Grup, bu çalışma ile cinsel kimlikleri normalleştirmeye katkı sağlamıştır. Act Up ve Gran Furry ikilisi sanat objeleri üreticisi olmaktan çok göstergelerin yöneticisidir ve yapıtları daha çok izleyiciyi, sloganların aktif okuyucularına dönüştürmektir. Böylelikle yapıt yazının slogan olarak sunumuyla seyirci ile anlam kazanır.

\section{Görsel 5}

Öpüşmek Öldürmez: Açgözlülük ve Kayıtsızlık Öldürür

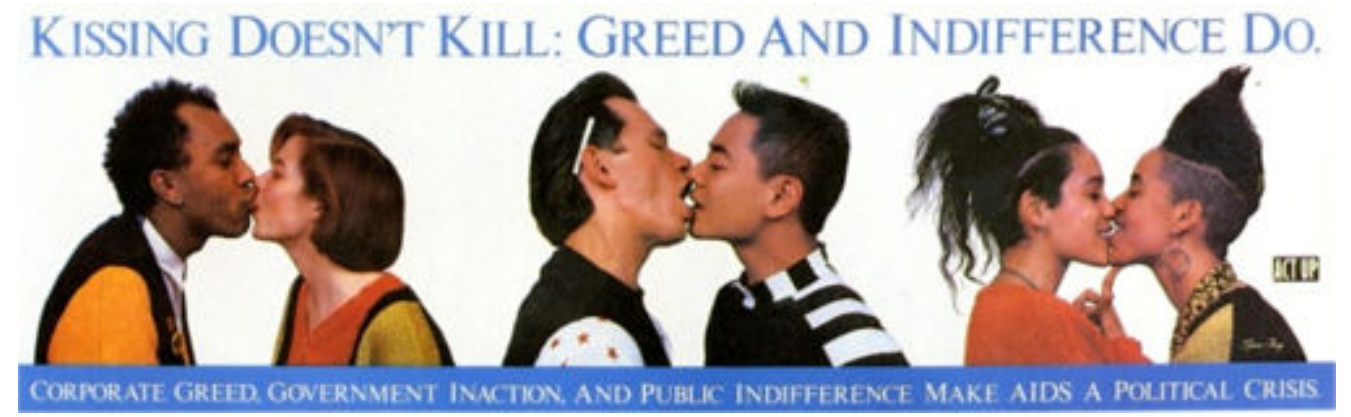

(Fury, 1989).

Kimlik küresel bir tema; ancak kimlik, Türkiye'nin Doğu pusulasında sanatçılar, hem kendi kültürlerini hem de dünyanın durumunu açıklama ve yorumlama eğilimindeler. Örüntüler ve eğilimler belirdikçe bu sanatçıların belirli temalarla eşleştirilir olduğu açıktır. Söz konusu güncel sanatçılar kimlik ve giydirilmiş kimlik temsilinde yazıyı, belgeleme ve kışkırtıcı provokatif söylemler oluşturmak amacıyla kullanmaktadırlar. Bu çerçevede Şener Özmen "aidiyet sorunum hiç olmadı, ne de kimlik bunalımlarım" (Oral, 2015) demesine rağmen sanatçının çalışmalarında varlık, kültürel kimlik ve toplumsal ortak belleğin bir çeşit yansımasına, yaşanan travmalarına tanık olunmaktadır. Özmen kimlik meselesini işlerken kullandığı metinlerinde sert politik bir dil kullanmıştır. Yaşamının doğduğu yere uzak bir coğrafyada nasıl biçimlendiği, nasıl bir bellek oluşturduğu ve nelere yol açtığı konusunda önemli toplumsal verilere ulaşılabilir olduğu için bu konu etrafinda eserler ortaya koyduğunu belirtmiştir (Çalıkoğlu, 
2005, s. 68). Sözcükleri kullanarak izleyici ile buluşan doğu kimlikli bir diğer sanatçı Halil Altındere ise, ulus, devlet, alt kültür ve gündelik yaşam içerisinde yaşanan durumlara karş1 üreterek ironik bir dil oluşturduğu çalışmalarıyla biliniyor. Çalışmalarında; kimlik kartı, bayraklar, pasaport, pul, banknot ve çeşitli devlet belgeleri gibi metinsel içeriği olan resmi nesneler kullanan sanatçı, mizansen, politik ve eleştirel bir yaklaşımla devlet hegemonyasına karşı seyirciyi düşünmeye teşvik ederek izleyene politik bir bakış açısı deneyimi sunar. Altındere, fotoğraf, dijital baskı, hazır nesne gibi çeşitli araçları kullanarak kimlik olgusuna odaklandığı Görsel 6'daki çalışmasında, nüfüs cüzdanı ile kimliği ilişkilendirmiştir. Sanatçı, 6 adet kimlik belgesinin, üzerinde bulunan fotoğrafların yer değiştirmesi ile yaşadığ dil yardımıyla, klişeleşmiş bir söylemle deşifre etmiştir.

\section{Görsel 6}

Tabularla Dans, 6 Kimlik, Değiştirilebilir Boyut

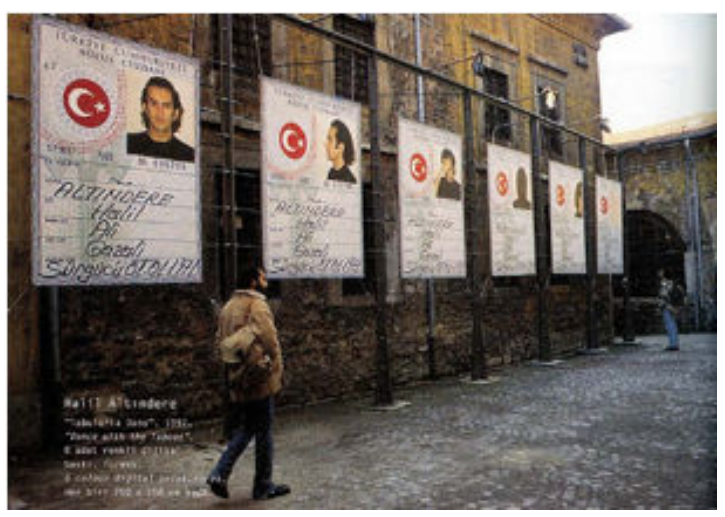

(Altındere, 1997).

Britanya'nın tanınmış sanatçılarından biri olan Grayson Perry, psikoterapinin sonucunda bir otoportre gibi ürettiği çalışmalarında, yazı arayıcılığıyla kimlik ve giydirilmiş kimlik kavramını ele alarak izleyicilerle iletişim kuran bir sanatçıdır. Metinsel içerikli pratiklere eserlerinde sıkça başvurarak, ulus, aile, cinsiyet, çoklu kimlik gibi kavramları sorgulamaktadır. Kimlik üzerinden ürettiği işlerinde yazıyı, mesaj verme ve dikkati bir yöne çekme amacıyla, kimliğini değiştiren ya da kimliği değişen sıradan insanları ele alarak sunmaktadır. Sanatçının eserlerinin pek çoğu otobiyografik unsurlar taşırken, "kimlik", "alter-ego" kavramlarına da çalışmalarında değinir (Kavrayan, 2019, s. 71). Eserlerinde, İngiliz kültürünü ve kimliğini metinler aracılığıyla çalışan Perry, bir duvarı kaplayan ve halıdan dokuduğu bir banknotun üzerine (Görsel 7) İngiliz kültürünü ve kimliğini kendi perspektifinden bakarak nakışla işlemiştir. Karmakarışık bir okuma deneyimi yaşatan "Comfort Blanket" isimli bu eser, İngiliz olmanın ne demek olduğu üzerinden düşünülerek tasarlanmıştır. İngiliz toplumunun zevk, beğeni ve politik görüşleri üzerine bir sosyolog ve antropolog gibi incelemeler yapan Perry'nin "Vote Tory" (Muhafazakarlara Oy Ver) (Görsel 8) isimli yapıtı ise çiçeklerle, kalplerle süslüdür. Tüm sanatçıların sol görüşlü olduğunu hiç sağ görüşlü bir sanatçıya rastlamadığından ve bu nedenle sol görüşlü sanatçıları kastettiğini söylediği çalışmasında, bu kişilerin portreleri kalpler, çiçekler ve tek boynuzlu atlar arasındadır. Perry'nin çalışmalarında hiç kuşkusuz metinsel içerikli dil, yapıtlarının temel ifade yöntemlerinden biri olup, İngiliz kültürünün yapı taşı olarak, her iki çalışmasında da yazı, baş rol olarak yerini almaktadır.

\section{Görsel 7}

Comfort Blanket

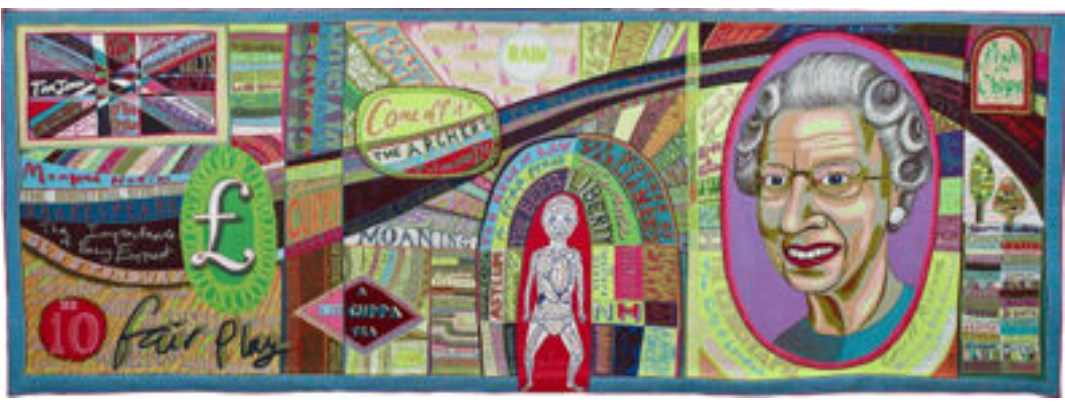

(Perry, 2014). 


\section{Görsel 8}

Vote Tory

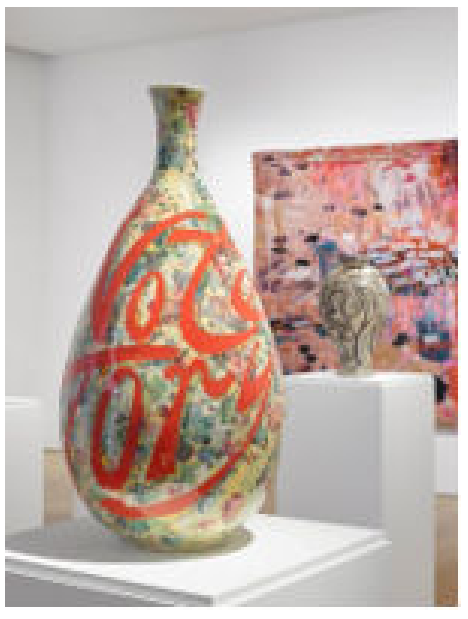

(Perry, 2019).

Yaşayan, hatırlayan ve hafıza aracılığı ile üreten sanatçı, belleğini kimlik meselesine temas ederek kullanmaktadır. Konu kapsamındaki sanatçı Gülsün Karamustafa'nın metinler üzerinden oluşturmaya çalıştığı yapıtlarında göç, siyasi kaynaklı göçebelik, feminizm, toplumsal cinsiyet tabularına dair eleştirel çözümlemeler gibi konular görülür. Görsel 9'da görülen “Kuryeler” adlı çalışma sanatçının kültürel kimlik ana başlığı adı altında ürettiği ilk çalışmalarından biridir. Karamustafa göçmen bir aileden geldiğinden kendi kişisel tarihinden yola çıkarak, bu çalışmayı babaannesinden dinlediği; savaş nedeniyle Kırım'dan Bulgaristan'a ve bir süre sonra Balkan Savaşı nedeniyle Bulgaristan'dan İstanbul'a göç etmiş bir ailenin hikâyesine odaklanan bir enstalasyon çalışmasındır. Çocukluğunda belleğine yerleşmiş anlatıları göçmen kimliğiyle yorumlayan sanatçı bu çalışmasında kumaş katları aralarına, kendisine ait nesneleri, metinleri, büyük bir titizlikle gizlendiği üç kapitone çocuk yeleği aracılığıyla görselleştirmiştir. Sınırları geçerken kendileri için önemli olduğunu düşündüklerini çocuk yeleklerinin içerisine dikerek gizlediklerinin hikâyesi olan "Kuryeler" yerellikten evrensele uzanan yoğun metin destekli bir yapıttır. İzleyici dikili bölmelere gizlenmiş şeylerin varlığını sezebiliyor ama tam olarak ne olduklarını okuyamıyor onlara dokunamıyor (Karamustafa, 2001, s. 53). Sanatçı tamamlayıcı ilişkiyi yazının görsel gücünü kullanarak sorgulamaktadir.

Karamustafa'nın, Görsel 10'da kadın eserleri kütüphanesinde sergilenmiş olan yapıtı babasının evrakları arasında bulup fotokopi ile çoğalttığı okul defterinden oluşuyor. Çalışma sanatçının bireysel kimliği üzerinden kolektif bir kimlik anlatısı oluşturmanın yanı sıra dönemin militarist düşünce yapısının nerelere kadar nüfus ettiğini ortaya koyuyor. Metinsel anlatım dilini kullanarak oluşturduğu “Okul Defteri” çalışması 1950'lerde çoğunlukla ezber odaklı olan ders konularının yetkin olmayan bir belleğe kazınan ideolojinin göstergelerini izleyiciye sunmaktadır. Eğitimle birlikte çocuk belleğine yerleştirilen, ulusal, kültürel, kurgusal kimlik temsilleri, hem bireysel hem de kollektif kimliğe yön veren yapay bir kimlik izi olarak Karamustafa'nın "Okul Defteri” adlı eserinde izleyiciye sunulmaktadır. Bireysel hafızadaki bir kimlik hikâyesi, özünde arşiv titizliğiyle, samimi bir etki yaratmak amacıyla el ile yazılmış ve sanat nesnesine dönüşmüştür.

\section{Görsel 9}

Kuryeler

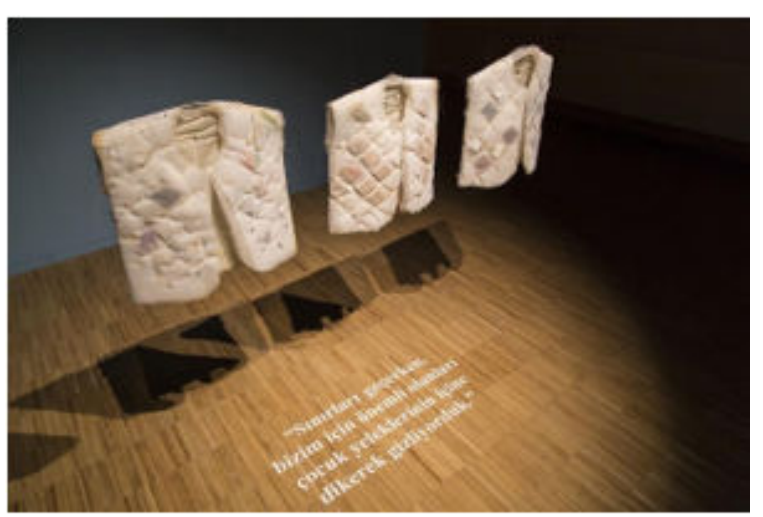

(Karamustafa, 1991). 


\section{Görsel 10}

Okul Defteri

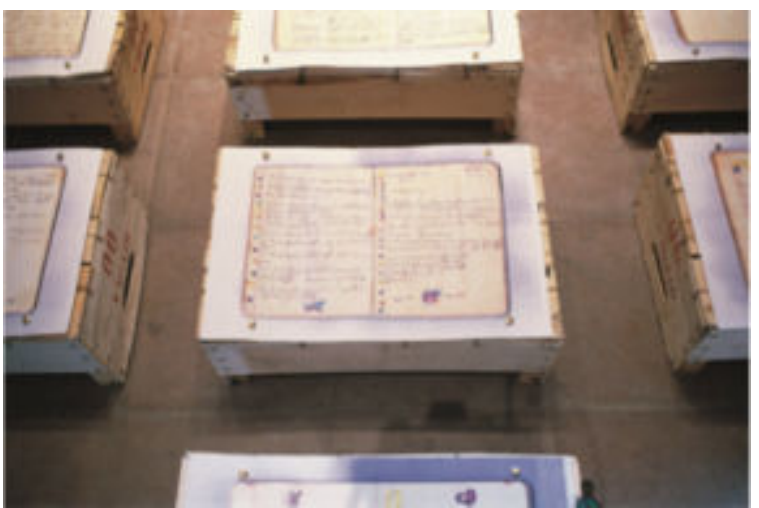

(Karamustafa, 1993).

Bedenin temsil ettiği kimlik parametrelerinin sınırını çizen sanatçılar bedeni kullanarak onu "kimlik arayışının mekanına" dönüştürmektedirler. Teiji Furuhashi'nin "Lovers" (Aşıklar) adlı dans ve tiyatro temelli multimedia enstalasyon ve performans çalışmasında (Görsel 11) bedeni, direk fiziksel varlığın orada olma olasılığı içerisinde konumlandırır. Odanın merkezindeki bir projeksiyon kulesinden yansıyan beş adam ve beş kadın figürü bir sırayla dans ederek boşlukta kaybolmakta ve yeniden ortaya çıkmaktadır.

Birbirini tetikleyerek sırayla duvardan duvara yansıyan bu projeksiyonda bedenler bir an içinde üst üste gelir; fakat yansımada bedenleri iletişime geçmez. Yazı ve ses eşliğindeki çalışmada "Aşk Her Yerde, Benimle Cinsel İlişsiye Girme, Dostum, Hayal Gücünü Kullan” gibi cümlelerle mesajlar verilmektedir (Rush, 2005, s. 164). Mekâna yerleştirilen yazılı ve hareketli görüntüler izleyiciyi konunun içine dâhil etmektedir. Furuhashi cinsel kimliğin süreç içinde dönüşebildiğini seyircinin uzamına ne ölçüde sızabildiğini görmeye çalışır. Kimliğin eylemsel yollarla dönüştürülebilir olduğuna inanan sanatçının yaratım süreçlerinde meydana getirdiği kimlik inşasını anlayabilmek için ortaya koyduğu görüşleri çalışmasını anlamak adına büyük bir öneme sahiptir.

\section{Görsel 11}

Lovers

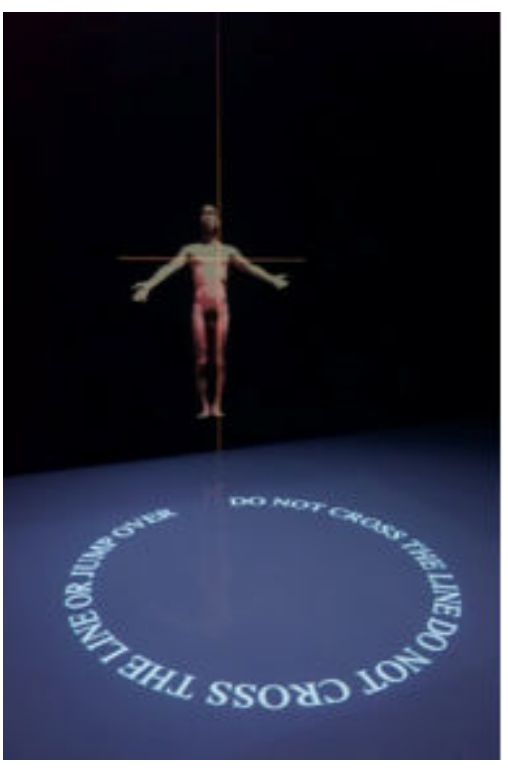

(Furuhashi, 1996).

"Lovers" adlı çalışmada da incelendiği üzere sanatçılar yerleşik kimlik algısıyla oynayan tutumlarla da hareket ederler. Ancak güncel sanatta izleyicinin bir esere sadece bakıp etkilenmesi yeterli değildir. İzleyici çalışmanın alt felsefesini ve çalışmadaki kavramsal içeriği anlamak zorundadır. Bunun yolu da esere dair çözümsel analizler yapmaktır. Furuhashi, bu performans çalışmasında yazıyı, imgeler üzerinden hareketle, içeriği anlamamızı sağlayan sistematik bir araç olarak kullanmıştır. Kimlik kavramı üzerinden çalışmaya yapılacak her türlü yorum, metinsel açıklamalar olmaksızın, sanatçının ve izleyicinin temas ettiği konuların dışında kalacaktır. 


\section{Sonuç}

Kimlik, politikadan felsefeye, psikanalizden sanata ele alınan bir kavram olduğu için, üretim sürecinde kimliklerini yapıtlarıyla birlikte inşa eden sanatçıların sorgulamaları üzerine bir inceleme, günümüz sanat anlayışına da yansımıştır. Çoğul kimlikler, güncel sanat üretimlerine dönüştürülerek, toplumunun ortak kültür hafızasına yerleşmiştir.

Farklı disiplinleri, çeşitli materyalleri ve yöntemleri, görsel imgeleri, tecrübelerinden, tarihten, gözlemlerinden referans alarak aynı potada birleştiren günümüz sanatçısı, çoklu kimliklerin ifadesinde dilin temsili olan yazıyı da bir yöntem olarak kullanmıştır. Sanatçıların örnek işlerinde sözcüklerle, cümlelerle kurulan metinsel anlatım dili kimliğin belirginleştirildiği parametrelerle, sanatın dönüşümüne ve çözümüne yönelik bir ifade biçimi olarak önemli bir görev üstlenmektedir. Kimlik ve kimlik temsilleri doğrultusunda üretilen metinsel içerikli anlatım yöntemleri ile politik bir farkındalık yaratılmıştır. Güncel sanat eserlerinde yazının kullanımı, bireysel kimlikler kadar, kendi ifade biçimini arayan, ötekileştirilen ve kıyafet gibi giyilip çıkartılan otobiyografik yeni kimliklerin en somut sözcüsü olmaktadır.

Makalede kullanılan öncül ve güncel örneklerde sanat yapıtlarının altında yatan derin felsefi düşünceyi sanatçılar disiplinler arası bir yaklaşımla aktarırken; aynı zamanda özünde var olan bireysel kimlikleri yeniden stilize ederek ve yeni argümanlar oluşturarak sanatçının yaratma sürecine kaynak sağlamıştır. Özellikle sanatçılar izole edilen kimliklere özgürlüklerini kazandırmak isterken burada izleyicinin anlamlandırma sürecinde yazının kullanımı, çoklu kimlikleri okuma ve ifade etme pratiğinin ne denli önemli olduğunu gözler önüne sermiştir. Farkındalık yaratmayı amaçlayan çalışmalar özellikle kimlik ve kimlik kavramlarını konu eden güncel sanatçıların, anlatılıp dile gelmemiş, belki henüz yaşanmamış ama yaşanabilir olanlara ve ihtimallere de açık kapı bırakan bir kimlik temsiliyeti çizmeye çalıştıkları görülmektedir. 


\section{Kaynakça}

Akay, A. (2000). Michel Foucault'da iktidar ve direnme odaklart. Bağlam Yayınları.

Altındere, H. (1997). Tabularla dans, 6 kimlik, değiştirilebilir boyut [Fotoğraf]. https://mehmetayaz.blogspot. com/2010/02/40-yl-once-surgucu-de-nufus-mudurlugu.html

Artun, A. (2013). Çăğdaş sanat ve kültüralizm, kimlik ve estetik. (T. Birkan, N. Örge ve E. Gen, Çev.). İletişim Yayınlar1.

Çabuklu, Y. (2004). Postmodern toplumda kriz ve siyaset. Kanat Kitap.

Çalıkoğlu, L. (2005). Çăgdaşs sanat konuşmaları. Yapı Kredi Yayınları.

Deleuze, G., \& Guattari, F. (1991). Kapitalizm ve şizofreni I-II. (A. Akay, Çev.). Bağlam Yayınları.

Emin, T. (1997). Fantastic to feel beautiful again, neon [Fotoğraf]. SFMOMA. https://www.sfmoma.org/artwork/ $\underline{99.489 /}$

Emin, T. (2004). Hate and power can be a terrible thing [Afiş]. TATE. https://www.tate.org.uk/ art/artworks/emin-hate-and-power-can-be-a-terrible-thing-t11891

Foster, H. (2011). Sanat siyaset, kültürel direniş. İletişim Yayınları.

Furuhashi, T. (1996). Lovers [Fotoğraf]. Textures. http://www.textures-platform.com/?p=3355

Fury, G. (1989). Öpüşmek öldürmez: Açgözlülük ve kayıtsızlı öldürür [Afiş]. The Atlantic. https://www.theatlantic.com/entertainment/archive/2012/01/how-aids-was-branded-looking-back-at-act-updesign/251267/

Gleason, P. (2006). Identifying identity. B. Ashcroft, G. Griffiths ve H. Tiffin (Der.), The post-colonial studies reader (2. Edition) içinde. Routledge.

Heartney, E. (2008). Akbank kültür ve sanat dizisi: Sanat ve bugün. (O. Akınhay, Çev.). Agora Kitaplığı.

Hicks, A. (2015). Küresel sanat pusulası: 21.yüzyıl sanatında yeni yönelimler. Yapı Kredi Yayınları.

Karamustafa, G. (1991). Kuryeler [Fotoğraf]. Saltonline. https://saltonline.org/tr/664/atolye-ipucu-gulsunkaramustafa

Karamustafa, G. (1993). Okul defteri. Salt Araştırma. https://archives.saltresearch.org/handle/ 123456789/189675

Karamustafa, G. (2001). Trellis of my mind: Works, 1998-2000. Mataş Yayınları.

Kavrayan, Ç. (2019). Çağdaş sanat ve kimlik: Grayson Perry eserleri üzerinden bir inceleme. Insan \& Insan Dergisi, 6(19), 63-77. https://doi.org/10.29224/insanveinsan.407617

Marshall, G. (2000). Sosyoloji sözlüğü. Bilim Sanat Yayınları.

Mathews, G. (2004). Global culture/individual identity: Searching for home in cultural supermarket. Routledge.

Newman, B. M., \& Newman, P. R. (1978). The concept of identity: Research and theory. Adolescence, 13(49), 157-166. https://europepmc.org/article/med/352102

Ong, W. J. (2013). Sözlü ve yazllı kültür. Metis Yayınları.

Oral. S. (2015, 24 Mart). Çıkış var mı yahut sahi, nasıl bir şey barış?. T 24 Bă̆ımsız İnternet Gazetesi. https://t24.com.tr/k24/yazi/senerozmen.398

Perry, G. (2014). Comfort blanket [Fotoğraf]. Art Basel. https://www.artbasel.com/catalog/artwork/18906/ Grayson-Perry-Comfort-Blanket

Perry, G. (2019). Vote Tory [Seramik]. Evening Standard. https://www.standard.co.uk/go/london/arts/graysonperry-review-victoria-miro-a4244771.html

Rush, M. (2005). New media in art. Thames \&Hudson World of Art.

Sarup, M. (1995). Post-yapısalcılık ve postmodernizm. (B. Güçlü, Çev.). Ark Yayınları.

Serter, N. (1996). Giydirilmiş insan kimliği. Der Yayınları.

Şimşek, S. (2002). Günümüzün kimlik sorunu ve bu sorunun yaşandığ 1 temel çatışma eksenleri. Uludağ Üniversitesi Fen-Edebiyat Fakültesi Sosyal Bilimler Dergisi. 3(3). 29-39. https://dergipark.org.tr/tr/download/ article-file/214786 
Tezkan, M. (2018, 21 Nisan). Kara kum. Galerist. http://www.galerist.com.tr/tr/nilyalter-secili-eserler

Weedon, C. (2004). Culture and identity: Narratives of difference and belonging. Berkshire.

Weeks, J. (1998). Farklılı̆̆ın değeri kimlik: Topluluk-kültür-fark. (İ. Sağlamer, Çev.). Sarmal Yayınları.

Yalter, N. (1975). Başsız kadın veya göbek dansı [Video]. Artful Living. https://www.artfulliving.com.tr/sanat/nilyalter-ve-gorunmeyenler-i-9151

Yalter, N. (2016). Şu gurbetlik zor zanaat zor [Fotoğraf]. Demokrat Haber. https://www.demokrathaber.org/denizgezmis-nil-yalter-ve-gocmen-hayatlar-makale.10383.html 